\title{
Evaluation of Noise in the Vicinity of a Hospital and a Gated Community
}

\author{
Paulo Henrique Trombetta Zannin ${ }^{(\mathbb{B}}$, Mirrê Liluz Milanês, \\ Marcus Vinícius Manfrin De Oliveira Filho
}

Mechanical Engineering Department, Federal University of Paraná, Laboratory of Environmental and Industrial Acoustics and Acoustic Comfort, Curitiba, Brazil

Email: paulo.zannin@gmail.com

How to cite this paper: Zannin, P. H. T., Milanês, M. L., \& De Oliveira Filho, M. V. M. (2019). Evaluation of Noise in the Vicinity of a Hospital and a Gated Community. Current Urban Studies, 7, 59-75. https://doi.org/10.4236/cus.2019.71004

Received: February 19, 2019

Accepted: March 17, 2019

Published: March 20, 2019

Copyright $\odot 2019$ by author(s) and Scientific Research Publishing Inc. This work is licensed under the Creative Commons Attribution International License (CC BY 4.0).

http://creativecommons.org/licenses/by/4.0/

\begin{abstract}
An evaluation was made of the acoustic environment of the Green Line North (GLN) by noise mapping calculations. In addition, the equivalent sound pressure levels, $\mathrm{L}_{\text {eq }}$, that reach the facades of a residential building and a hospital located along the GLN, were simulated to determine the noise levels to which they are subjected. The simulated noise levels were compared with the maximum allowable noise levels established by Curitiba Municipal Law and by the Brazilian standard on Noise Assessment in Populated Areas. It was concluded unequivocally that, in the current situation, noise pollution affects the hospital and the gated community. A simulation of heavy vehicle traffic reduction was performed, aiming at evaluating the impact of this mitigation measure. Even the reduction of number of heavy vehicle to $10 \%$ of the original number proved to be insufficient to attend values established by the municipal law and the Brazilian standard.
\end{abstract}

\section{Keywords}

Noise Pollution, Hospital, Noise Mapping, Noise Measurements, Vehicle Noise, Gated Community

\section{Introduction}

Noise in cities is a global problem, whether small, medium or large cities. Sound pressure levels in urban environments have produced harmful effects on people's health. Four revisions recently written, one in 2017 and three in 2018 show the extent of the noise problem in cities (Licitra et al., 2017; Engel et al., 2018; Asdrubali \& D’Alessandro, 2018; Morillas et al., 2018).

According to Fiedler and Wilhelm (2011): "In Germany, around 70\% of the population is disturbed by noise". Fiedler and Wilhelm (2011) also point out 
that: "The main source of noise comes from traffic noise". A similar conclusion is presented by Morillas et al. (2018), where they state that: "From a temporal and spatial point of view, it is now recognized that the main source of noise in cities comes from road traffic".

Several studies have focused on the problem of environmental noise affecting educational areas, for example (Zannin et al., 2013a; Zannin et al., 2013b; Minichilli et al., 2018).

Several studies have shown a correlation between noise pollution and health problems such as irritability, poor concentration, insomnia, headache (Muzet, 2007; Fiedler \& Wilhelm, 2011; Dratva et al., 2012; Babisch et al., 2012; Engel \& Zannin, 2017).

In the city of Curitiba, Brazil, interviews conducted with 863 people revealed that urban traffic noise is considered a major source of discomfort (Zannin et al., 2002). Rapid population growth in the municipality of Curitiba over recent decades resulted in urban sprawl into previously sparsely populated areas. This included expansion along both sides of the old BR-116 highway located within the urban perimeter of Curitiba, transforming these areas into densely populated neighborhoods (Zannin \& Sant'Ana, 2011; Bunn et al., 2016).

Due to this populational increase, BR-116 highway renewed and became known as Green Line (Zannin \& Sant'Ana, 2011). The structural composition of the Green Line is defined as a ten-lane avenue (including express bus lanes and two parking lanes), a bike path, a linear park, new lighting system, landscaping and road signs. The Green Line (GL), which covers 18 kilometers, was divided into two sections: 1) the South section, approximately $10 \mathrm{~km}$, between the neighborhoods of Pinheirinho and Jardim Botânico/UFPR; and 2) the North section, approximately $8 \mathrm{~km}$, between the neighborhoods of Jardim Botânico/UFPR and the Atuba Interchange. Sections 1 and 2 comprise 55\% and 45\%, respectively, of the Green Line.

Studies in the vicinity of noise sensitive areas, such as hospitals, have also been developed by researchers such as Busch-Vishniac et al., 2005; Tijunelis et al., 2005; Applebaum et al., 2010; Andrade et al., 2016; Zannin \& Ferraz, 2016; Ilic et al., 2018; Loupa et al., 2019. Together, other studies have analyzed the issue of environmental noise and its influence on urban dwellers, in their homes, in their apartments, in their residential buildings, in residential condominiums, in gated community, etc. (Mahbub et al., 2009; Oliveira-Filho \& Zannin, 2015; Gozalo \& Morillas, 2016; Paiva et al., 2019).

This study describes the impact of noise pollution on two noise sensitive areas-a hospital and a gated community located along the-Green Line North-GLN.

\section{Materials}

Ambient noise pollution assessments in Brazil are governed by the NBR 10151 
standard (2000). Table 1 lists the permissible sound levels according to region and time of day, according to NBR 10151 (ABNT, 2000). Curitiba's Municipal Law No. 10625 (2002) establishes regulations on urban noise, public protection and welfare, and makes other provisions. The law covers three time frames, namely: 1) Daytime-from 07:01 a.m. to 7:00 p.m.; 2) Evening-from 7:00 a.m. to 10:00 p.m.; and 3) Nighttime-from 10:01 p.m. to 7:00 a.m.

The city of Curitiba is divided into several zones for specific uses, e.g., special commercial sector, historical sector, special educational zone, industrial zone, residential zone, mixed use zone, among others. Curitiba's Green Line is situated in a region of the city called BR-116 Transition Zone and BR-116 Special Sector, established by Law No. 10625 (PMC, 2002). Curitiba Municipal Law No. 10625 states that noise immissions from any industrial, commercial, service-related, religious, recreational and truck loading/unloading activities shall not exceed the sound pressure levels permitted for their respective zones of use (see Table 2).

The objectives of this study included the following analyses: Analysis I-Calibration of the model based on a comparison of the measured and simulated noise levels; Analysis II-Evaluation of the effect of reduced flow of heavy vehicle traffic on the noise levels, based on computational simulation. This assessment was performed on Lot 1 (see Table 5); Analysis III-Computational analysis of noise at the facades of buildings (Vita Hospital and a gated community). On the noise maps, the noise levels are represented by a color scale (see Figure 1).

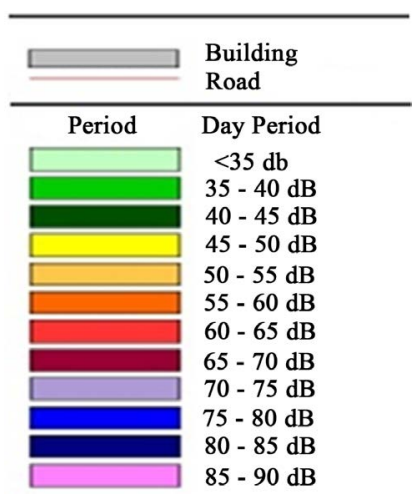

Figure 1. Color scale of the levels indicated by the predictor software.

Table 1. Sound pressure levels permitted for outdoor environments, according to NBR 10151-Brazilian association of technical standards.

\begin{tabular}{ccc}
\hline Typeofregions & Daytime dB (A) & Nighttime dB (A) \\
\hline Farmsandranches & 40 & 35 \\
Strictly urban residential area with hospitals or schools & 50 & 45 \\
Área mista, predominante residencial & 55 & 50 \\
Mixedarea, predominantlyresidential & 60 & 55 \\
Mixed area of commercial establishments and offices & 65 & 55 \\
Predominantly industrial area & 70 & 60 \\
Industrial andservices zone & 70 & 60 \\
\hline
\end{tabular}


Table 2. Maximum sound pressure levels permitted by Curitiba Municipal Law No. 10625/2002-Equivalent continuous sound pressure level, Leq.

\begin{tabular}{cccc}
\hline Zones ofUse & $\begin{array}{c}\text { Daytime } \\
\text { 7:01 am - } \\
\text { 7:00 p.m. }\end{array}$ & $\begin{array}{c}\text { Evening } \\
\text { 7:01 am - } \\
\text { 22:00p.m. }\end{array}$ & $\begin{array}{c}\text { Nighttime } \\
\text { 22:01p.m - } \\
\text { 7:00a.m. }\end{array}$ \\
\hline Residential zone, Hospital & $55 \mathrm{~dB}(\mathrm{~A})$ & $50 \mathrm{~dB}(\mathrm{~A})$ & $45 \mathrm{~dB}(\mathrm{~A})$ \\
$\begin{array}{c}\text { Transition and special zones, } \\
\text { ZR4 (gated Community) }\end{array}$ & $60 \mathrm{~dB}(\mathrm{~A})$ & $55 \mathrm{~dB}(\mathrm{~A})$ & $50 \mathrm{~dB}(\mathrm{~A})$ \\
$\begin{array}{c}\text { Central Zone and Special Sectors } \\
\text { Green Line - ZT-BR116 and SE-BR116 }\end{array}$ & $65 \mathrm{~dB}(\mathrm{~A})$ & $60 \mathrm{~dB}(\mathrm{~A})$ & $55 \mathrm{~dB}(\mathrm{~A})$ \\
Industrial and services zone & $70 \mathrm{~dB}(\mathrm{~A})$ & $60 \mathrm{~dB}(\mathrm{~A})$ & $60 \mathrm{~dB}(\mathrm{~A})$ \\
\hline
\end{tabular}

\section{Methods}

\section{Data collection}

Sound Level Measurements - Vehicle Count - Model Calibration - Average Speed

The equipment used for data acquisition was: 1) Brüel \& Kjaer type 2250 (BK) sound level meter; 2) BK Predictor 7810 version 6.2 acoustic mapping software. Each measurement lasted 10 minutes (Zannin et al., 2013a; Fiedler \& Zannin, 2015). The measurements were taken as recommended by the German standard RLS 90 (1990) used for road traffic noise assessments, which specifies that the position of the sound pressure level meter should be 25 meters from the middle of the road.

The vehicles, which were counted visually and computed on a spreadsheet, were separated into motorcycles, light vehicles and heavy vehicles (buses and trucks), as described by other authors (Lee et al., 2008; Romeu et al., 2011; Zannin et al., 2013a; Fiedler \& Zannin, 2015). For the reader's clarification, in accordance with Resolution No. 15/1998 of CONTRAN-National Traffic Council, light vehicles are defined here as vehicles weighing less than $3856 \mathrm{~kg}$, for transporting passengers, cargo or for mixed use, and heavy vehicles as those weighing more than $3856 \mathrm{~kg}$. To use these data in the model, the vehicle count was undertaken simultaneously with the measurements and in the two directions of the road. The meter was mounted on a tripod and positioned $1.2 \mathrm{~m}$ above the ground. The average speed was estimated by driving a vehicle along the section of the road under study, and checking the speedometer to determine the approximate average speed at each point. It should be noted that the measurements, vehicle counts and average speed estimates were performed from Monday to Friday, avoiding rush hours, weekends and holidays.

Measurements were taken in the morning between 9 a.m. and 11 a.m., and in the after-noon between 2 p.m. and 4:30 p.m. (Guedes et al., 2011; Bunn et al., 2016). The data were collected over a period of 120 days, between August and November 2012. The measured sound pressure levels were compared to the limits shown in Table 2. 
To measure the sound levels, 23 points spaced about 350 meters apart were selected, corresponding to a total of 8,050 meters, which is the approximate length of the Green Line North (GLN), see Table 3. The measurement procedure was based on the methodology developed by Zannin and Sant'Ana (2011). The first measuring points are located in the proximities of the Federal University of Paraná, UFPR (see Figure 2) and the last measuring point is located at the Atuba Interchange (see Figure 3).

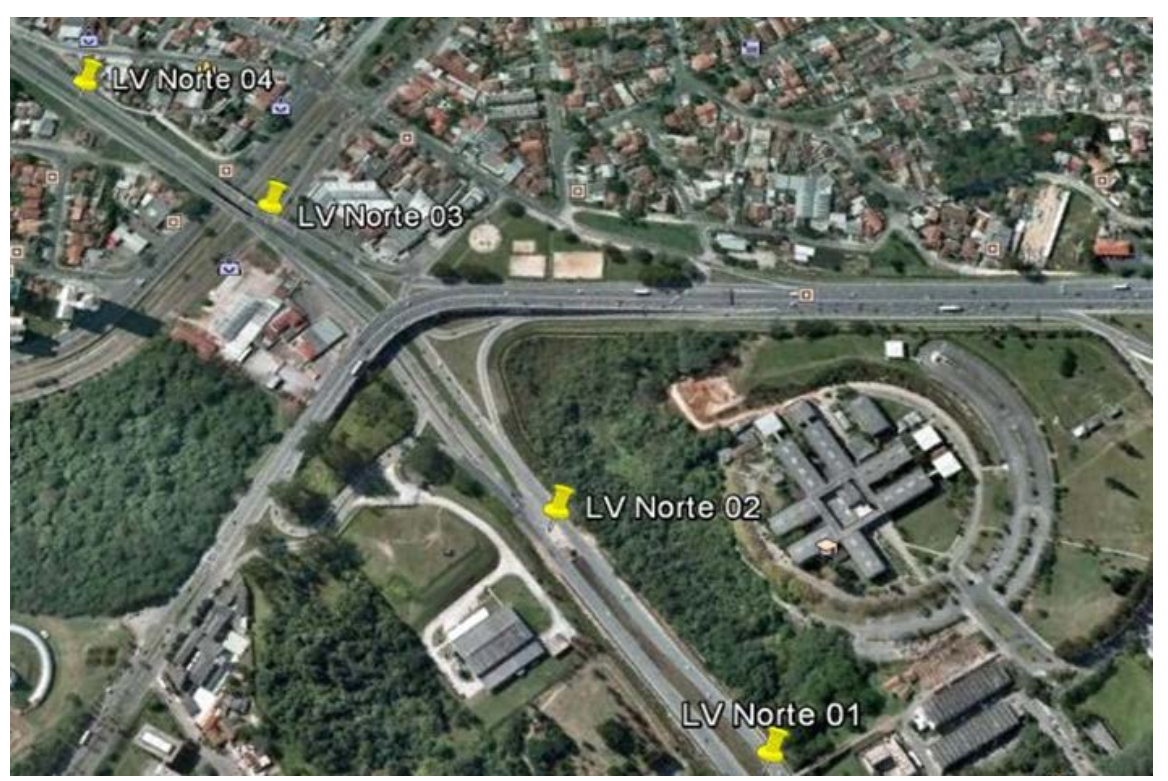

Figure 2. Location of measuring points 01 to $04-$ As listed in Table 5-Lot 1. Source: Google Maps (2012).

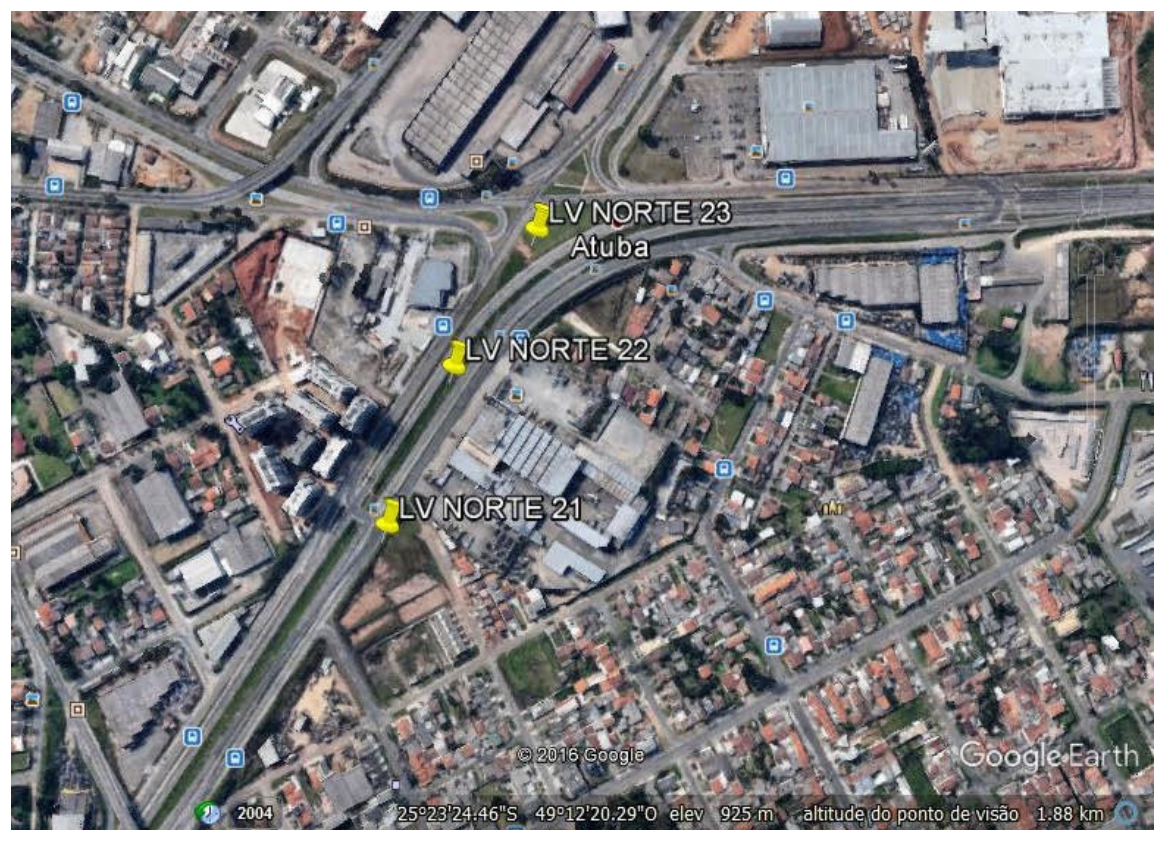

Figure 3. Location of measuring point 23 - Atuba Interchange-As listed in Table 5-Lot 6. Source: Google Maps (2012). 
Table 3. Average vehicle flow per hour at each measuring point.

\begin{tabular}{|c|c|c|c|c|c|c|c|c|c|}
\hline \multirow{2}{*}{ Points } & \multicolumn{3}{|c|}{ Vehicles } & \multirow{2}{*}{$\begin{array}{l}\text { Total } \\
\text { hour }\end{array}$} & \multirow{2}{*}{ Points } & \multicolumn{3}{|c|}{ Vehicles } & \multirow{2}{*}{$\begin{array}{l}\text { Total } \\
\text { per }\end{array}$} \\
\hline & Light & Motorcycles & Heavy & & & Light & Motorcycles & Heavy & \\
\hline 1 & 2800 & 279 & 300 & 3379 & 14 & 2824 & 398 & 222 & 3444 \\
\hline 2 & 2800 & 279 & 300 & 3379 & 15 & 2238 & 438 & 196 & 2872 \\
\hline 3 & 2222 & 241 & 350 & 2813 & 16 & 2222 & 367 & 215 & 2804 \\
\hline 4 & 2222 & 241 & 350 & 2813 & 17 & 2238 & 438 & 196 & 2872 \\
\hline 5 & 2222 & 241 & 350 & 2813 & 18 & 2086 & 431 & 197 & 2714 \\
\hline 6 & 2222 & 241 & 350 & 2813 & 19 & 2130 & 345 & 211 & 2686 \\
\hline 7 & 2222 & 241 & 350 & 2813 & 20 & 1938 & 420 & 174 & 2532 \\
\hline 8 & 2251 & 218 & 279 & 2748 & 21 & 1192 & 168 & 204 & 1564 \\
\hline 9 & 2251 & 218 & 279 & 2748 & 22 & 1624 & 136 & 364 & 2124 \\
\hline 10 & 2420 & 218 & 212 & 2850 & 23 & 2200 & 367 & 220 & 2787 \\
\hline 11 & 2550 & 222 & 318 & 3090 & & & & & \\
\hline 12 & 2824 & 398 & 216 & 3438 & & & & & \\
\hline 13 & 2824 & 398 & 216 & 3438 & & & & & \\
\hline
\end{tabular}

Several input data are required to calibrate the software for simulations as close as possible to the real situations. These data were imported into the Predictor ${ }^{ø}$ software using Geographic Information System (GIS) files available in digital media. Another item of information needed to calibrate the software was a drawing of all the buildings, which was done manually based on a satellite photo. For the altimetric characteristics, a height of three meters was adopted for each floor in each building. For the Predictor ${ }^{\oplus}$ software to generate a noise map, it is necessary to delimit it by a grid containing the receiver points (grid noise map), whose distance will depend on the targeted accuracy. The less refined the grid the lower its accuracy and the faster the calculation of the maps. The grid should not exceed $10 \mathrm{~m} \times 10 \mathrm{~m}$ for the calculation of maps in urban agglomerations (Guedes \& Leite, 2007). Therefore, the grid size adopted for the calculation was $5 \mathrm{~m} \times 5 \mathrm{~m}$, allowing for better detailing of the noise maps (Guedes \& Leite, 2007; Lee et al., 2008; Fiedler \& Zannin, 2015). The height of the grid used in this study was four meters, following recommendations found in the current bibliography (Pinto \& Mardones, 2009; Murphy \& King, 2010; Guedes et al., 2011; Murphy \& King, 2011; Fiedler \& Zannin, 2015).

\section{Results and Discussion}

First, noise measurements were taken at the 23 points along the road, and the vehicle count (vehicles/hour, light, heavy and motorcycles) was done simultaneously. Table 3 lists the number of vehicles per hour, and Table 4 describes the measured and simulated equivalent continuous noise levels, Leq. Traffic composition is an important factor for environmental noise impact assessments because it directly affects the generation of noise in the area under study. Moreover, it is an item of the input data for computational simulations of noise pollution levels. Figure 4 shows the traffic composition in percentages, considering the data computed for the 23 measuring points. 


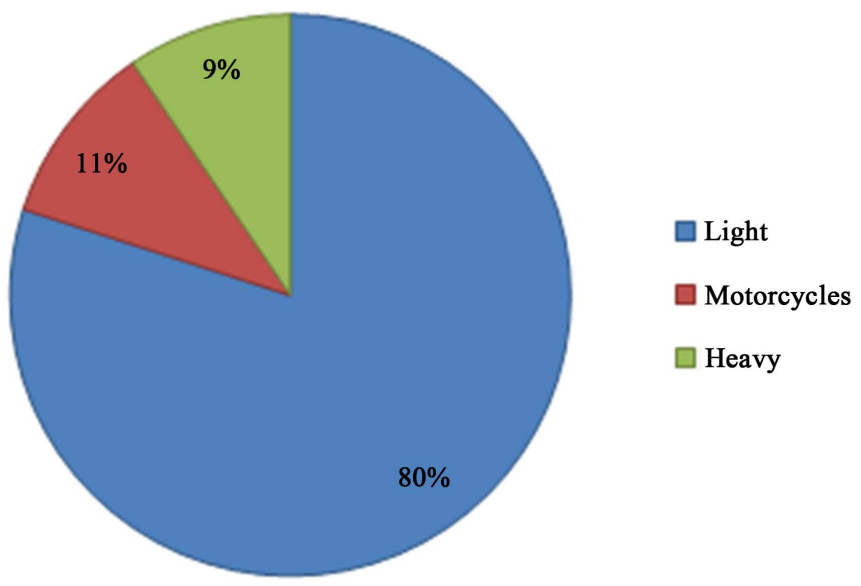

Figure 4. Percent composition of vehicle flow.

Table 4. Comparison of measured and simulated noise levels.

\begin{tabular}{|c|c|c|c|}
\hline \multirow{2}{*}{$\begin{array}{l}\text { Measurement } \\
\text { Points }\end{array}$} & \multicolumn{2}{|c|}{ Leq dB (A) } & \multirow{2}{*}{$\begin{array}{l}\text { Difference between measured } \\
\text { and simulated noise levels } \mathrm{dB}(\mathrm{A})\end{array}$} \\
\hline & Measured & Simulated & \\
\hline 1 & 72.9 & 76.8 & -3.9 \\
\hline 2 & 72.8 & 76.2 & -3.4 \\
\hline 3 & 78 & 77.2 & 0.8 \\
\hline 4 & 77.9 & 79.5 & -1.6 \\
\hline 5 & 76.5 & 74.8 & 1.7 \\
\hline 6 & 77.8 & 76.6 & 1.2 \\
\hline 7 & 80.8 & 80.5 & 0.3 \\
\hline 8 & 72.1 & 74.2 & -2.1 \\
\hline 9 & 78.2 & 76.1 & 2.1 \\
\hline 10 & 78.9 & 78.3 & 0.6 \\
\hline 11 & 77.2 & 76.5 & 0.7 \\
\hline 12 & 77.0 & 76.8 & 0.2 \\
\hline 13 & 77.9 & 77.4 & 0.5 \\
\hline 14 & 77.5 & 77.7 & -0.2 \\
\hline 15 & 80.1 & 78.4 & 1.7 \\
\hline 16 & 79.1 & 81.0 & -1.9 \\
\hline 17 & 77.8 & 78.4 & -0.6 \\
\hline 18 & 72.8 & 73.8 & -1 \\
\hline 19 & 75.1 & 77.3 & -2.2 \\
\hline 20 & 76.1 & 76.6 & -0.5 \\
\hline 21 & 72.9 & 76.7 & -3.8 \\
\hline 22 & 78.4 & 77.8 & 0.6 \\
\hline 23 & 73.8 & 77.7 & -3.9 \\
\hline
\end{tabular}

As can be seen in Table 4, the greatest difference observed between measured and simulated sound pressure levels was $3.9 \mathrm{~dB}(\mathrm{~A})$. These results are in agreement with recommendations in the current literature for the calculation of noise 
maps, which considers acceptable a difference between the measured and calculated values between 3 and $5 \mathrm{~dB}$ (A). Lee et al. (2008), in their work using noise mapping, indicate that a difference of up to $+/-3 \mathrm{~dB}(\mathrm{~A})$ between measured and calculated sound pressure levels can be accepted. Licitra and Memoli (2008) consider acceptable a difference of up to $+/-4.6 \mathrm{~dB}$ (A) between the calculated model and in situ measurements noise levels. Bies and Hansen (2002) indicate that the difference between the measured and simulated values can be up to $5 \mathrm{~dB}$ (A). After this comparison is made between the measured and calculated values, in which the values calculated for the model developed with the Predictor ${ }^{\circledR}$ software are considered reliable, several simulations can be made, as will be shown by the results described below. The GLN was divided into several maps (or lots) to facilitate its analysis and understanding. These lots comprise the 23 measuring points, as can be seen in Table 5 .

Table 5 lists the noise levels in the proximities of the highway that reach the façades of the buildings, based on the computer generated noise maps, and also compares these levels with the limits established by Curitiba Municipal Law No. 10625 and by the NBR 10151 standard. Thus, after the maps were calibrated-the measured and simulated data were compared as described earlier-simulations were made to calculate the sound levels reaching the façades of the gated community and of Vita Hospital. The daytime noise emission limits, which are $60 \mathrm{~dB}$ (A) and $65 \mathrm{~dB}(\mathrm{~A})$, respectively, were found to be exceeded.

The only exception was at lot 2 (see Table 5), which was under construction. Appendix 2 of Curitiba Municipal Law no. 10625 determines that, in such cases, the permitted daytime noise limit may reach up to $90 \mathrm{~dB}$ (A). Measurements were taken at five points along the section under construction, comprised between Delegado Leopoldo Belczak Street and Coronel Iraze Paes Brasil Street. The measured values ranged from 72 to $81 \mathrm{~dB}(\mathrm{~A})$, and were thus in compliance

Table 5. Sound pressure levels generated by vehicle traffic in the proximities of the highway and at the facades of the buildings.

\begin{tabular}{cccccccc}
\hline & & \multicolumn{2}{c}{$\begin{array}{c}\text { Averagespeed } \\
\text { (km/h) }\end{array}$} & \multicolumn{2}{c}{ Leq in $\mathrm{dB}$ (A) } & \multicolumn{2}{c}{$\begin{array}{c}\text { Requirements } \\
\text { compliedwith }\end{array}$} \\
\cline { 2 - 8 } & $\begin{array}{c}\text { Measuring } \\
\text { points }\end{array}$ & $\begin{array}{c}\text { Light } \\
\text { vehicles }\end{array}$ & $\begin{array}{c}\text { Heavy } \\
\text { vehicles }\end{array}$ & $\begin{array}{c}\text { In the } \\
\text { proximities } \\
\text { of the } \\
\text { highway }\end{array}$ & $\begin{array}{c}\text { At the } \\
\text { façades } \\
\text { of the } \\
\text { buildings }\end{array}$ & Law no. 10625 & $\begin{array}{c}\text { NBR } \\
10151\end{array}$ \\
\hline 1 & $1,2,3$ and 4 & 60 & 50 & 80 to 85 & 75 to 80 & No & No \\
2 & 5 to 9 & 60 & 50 & 80 to 85 & 75 to 80 & Yes & Does \\
3 & 10 to 13 & 80 & 70 & 80 to 85 & 75 to 80 & No & No \\
4 & 14 and 15 & 60 & 50 & 80 to 85 & 75 to 80 & No & No \\
5 & 16 to 18 & 75 & 65 & 80 to 85 & 75 to 80 & No & No \\
6 & 19 to 23 & 50 and 100 & 40 and 80 & 80 to 85 & 80 to 85 & No & No \\
\hline
\end{tabular}


with the regulations. The NBR 10151 standard does not mention environmental assessments, for example, when a construction work is in progress, as was the case with Lot 2 of measurements.

As can be seen in Figure 5 and Figure 6, the noise levels in the proximities of the GLN, corresponding to the region represented by navy blue, dark blue, purple, dark red and light red, exceed the limits established by the Municipal Law and by NBR 10151. A factor that aggravates the problem is visible in the region demarcated with an arrow, in Figure 6, Lot 4, where Vita Hospital is situated. This area is defined as a "hospital quiet zone" whose noise limit is set at $55 \mathrm{~dB}$ (A) by the Municipal Law and at $50 \mathrm{~dB}$ (A) by the NBR 10151 standard. In addition, the Municipal Law specifies that this quiet zone must cover a 200 meter radius around hospitals. Another sensitive zone can be seen in Figure 7, where a Gated Community, Lot 6 is located.

To examine the effect of reducing the flow of heavy vehicles as a possible means of mitigating the noise generated along the section, the behavior of the equivalent continuous sound pressure level, Leq, was simulated in different scenarios at two random points, for the purpose of illustration. The simulated scenarios involve the original traffic being reduced to $50 \%, 40 \%, 30 \%, 20 \%$ and $10 \%$ of the original heavy vehicle traffic at points 03 and 04 of Lot 6 . The results of these simulated reductions are shown in Figure 8. The average vehicle speed remained unchanged. As can be seen in Figure 8, the simulations of the percent reductions in heavy vehicle flow by half generate a decrease in sound levels of about $1.7 \mathrm{~dB}$ (A). This is confirmed by a study carried out by Richard (2013) in Germany and published in the journal Lärmbekämpfung, which states that: "The expected margin of reduction of sound levels in response to the adoption of individual mitigation measures, including, for example, the reduction in the percentage of heavy vehicles, ranges from 1 to $3 \mathrm{~dB}(\mathrm{~A})$ ". Bunn and Zannin, (2015) and Bunn et al. (2016) studied the acoustic field around the south section of the Green Line, simulating reductions in heavy vehicle flow, and found that

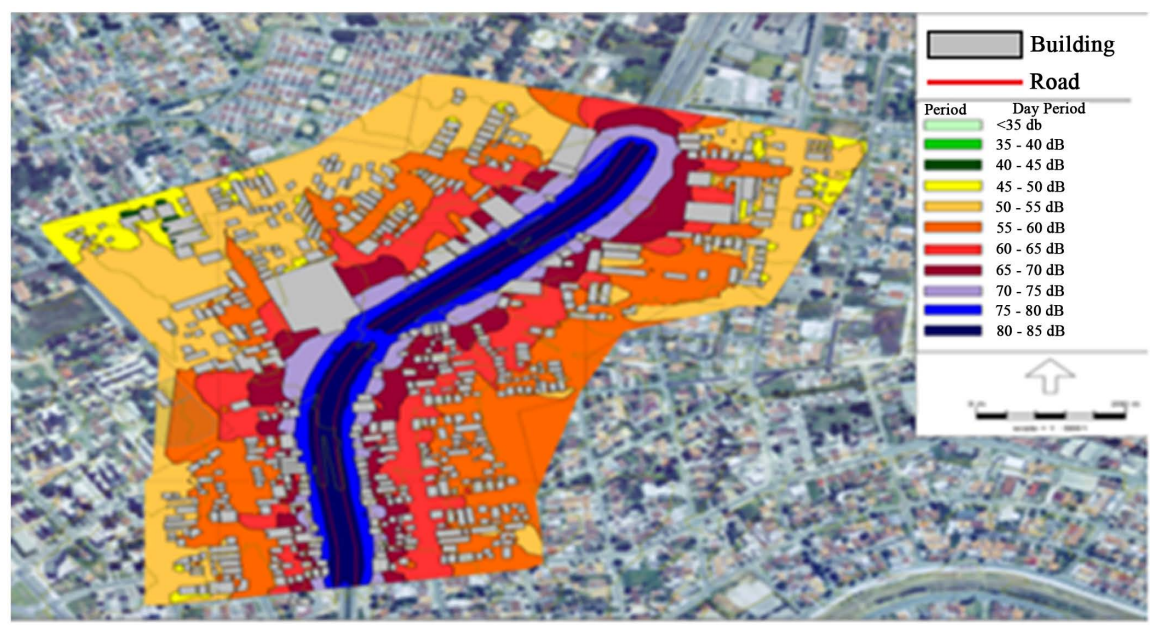

Figure 5. Computer simulation-Leq-of Lot 2. 


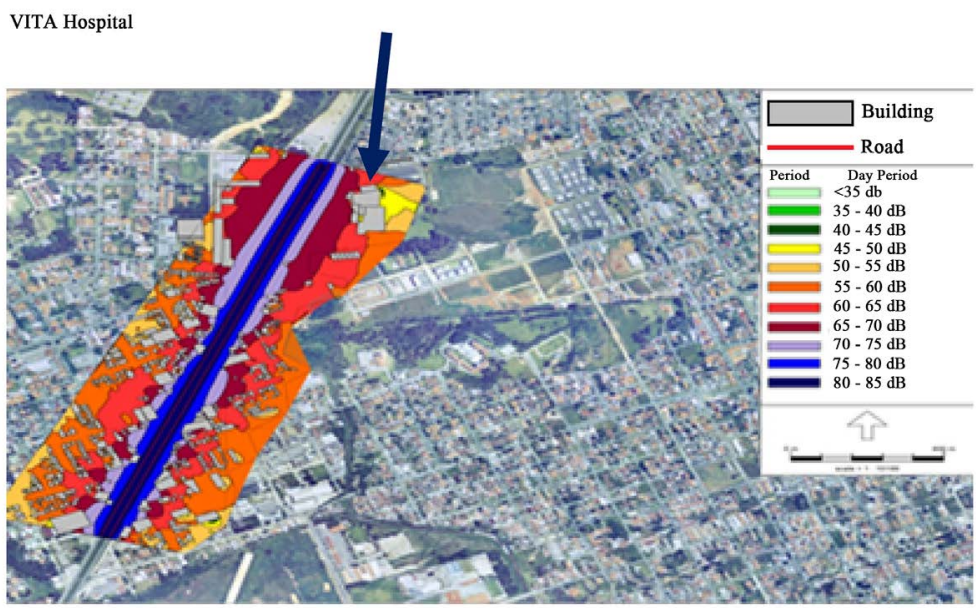

Figure 6. Computer simulation-Vita Hospital-Leq-of Lot 4.

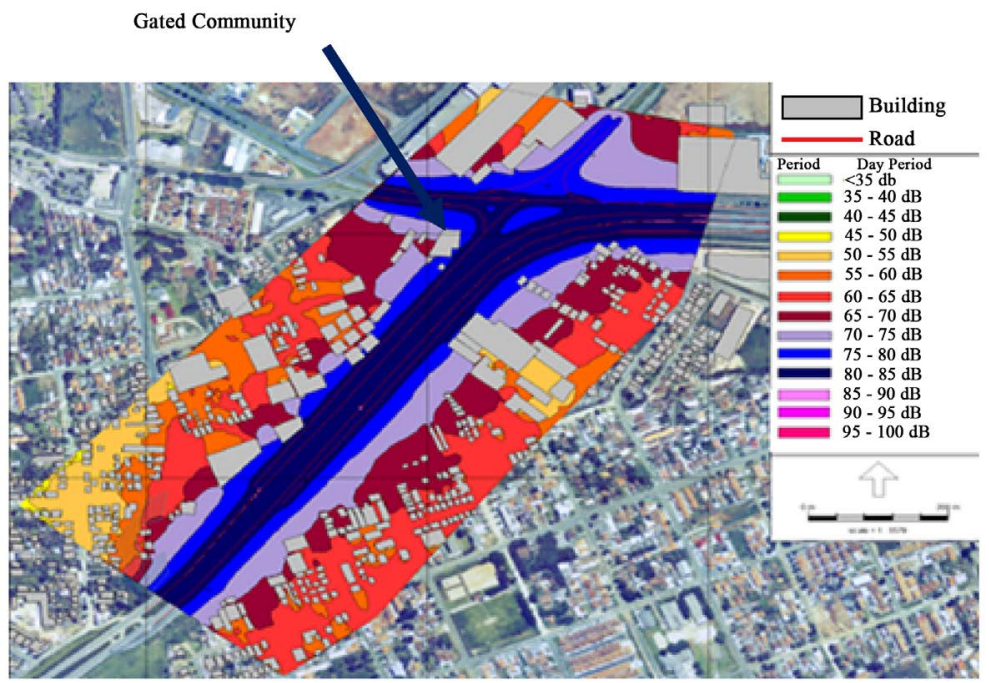

Figure 7. Gated Community.

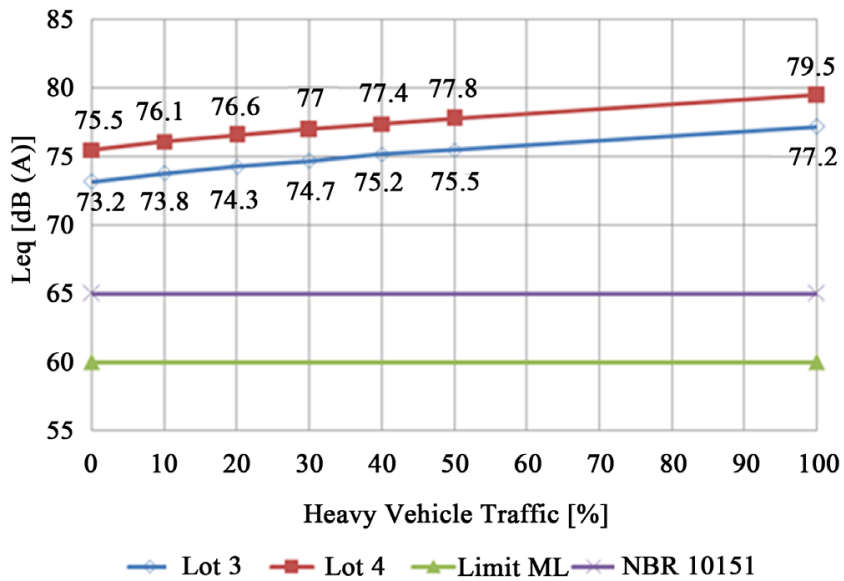

Figure 8. Comparison of the simulations representing the $50 \%$ to $10 \%$ reductions in heavy vehicle flow (ML-Municipal Law-Table 2 and NBR 10151-Brazilian Technical Standards-Table 1). 
the noise level decreased by about $2.5 \mathrm{~dB}(\mathrm{~A})$. The present study achieved comparable results, since the reduction of the sound levels fell within this range, i.e., from 1 to $3 \mathrm{~dB}(\mathrm{~A})$.

Figure 9 and Figure 10 show noise maps that consider the effect of the reduction of the percentage of heavy vehicles on the simulated sound levels.

From the above, it is clear the existence of noise pollution in the GLN. The measured and simulated sound levels surpass both the Brazilian standard for the evaluation of environmental noise and the Municipal Law on noise in the city of Curitiba. The simulation of the decrease in the flow of heavy vehicles from $50 \%$ to $10 \%$ proved to be incapable of substantial reductions in sound levels, being within the range of 1 to $3 \mathrm{~dB}(\mathrm{~A})$, that is, the noise reduction achieved is very small. This fact makes it appear that maps 10 and 11 have not altered their colors despite the decrease in the percentage of heavy vehicles. On the other hand, the reduction in sound levels, as previously reported, were similar to those found in current literature, as data found in Germany and even here in Brazil.

In GLN, we can observe the existence of a noise sensitive zone, a hospital and a residential area ZR4 (gated community) for which Table 2 shows the noise levels that should be in force during the daytime period.

Figure 11 represents the VITA Hospital building located 60 meters from the side road of the GLN. Areas such as hospitals and schools are more noise-sensitive and are classified by as quiet zones (ZR-1) by Curitiba Municipal Law $9800 / 2000$, which establishes regulations on zoning, land use and occupation in the Municipality of Curitiba. Tolerance to noise in these areas is lower than in other regions, and in this case, according to Municipal Law 10625, the daytime limit of $55 \mathrm{~dB}$ (A) must be observed. Moreover, this limit must extend to a 200 meter radius around hospitals.

In Figure 11, note that sound levels of $55 \mathrm{~dB}(\mathrm{~A})$ (orange) to $70 \mathrm{~dB}(\mathrm{~A})$ (wine red) reach almost the entire facade of Vita Hospital. These noise levels exceed



Figure 9. Computer simulation with $50 \%$ of the heavy vehicle traffic, Lot 1 . 


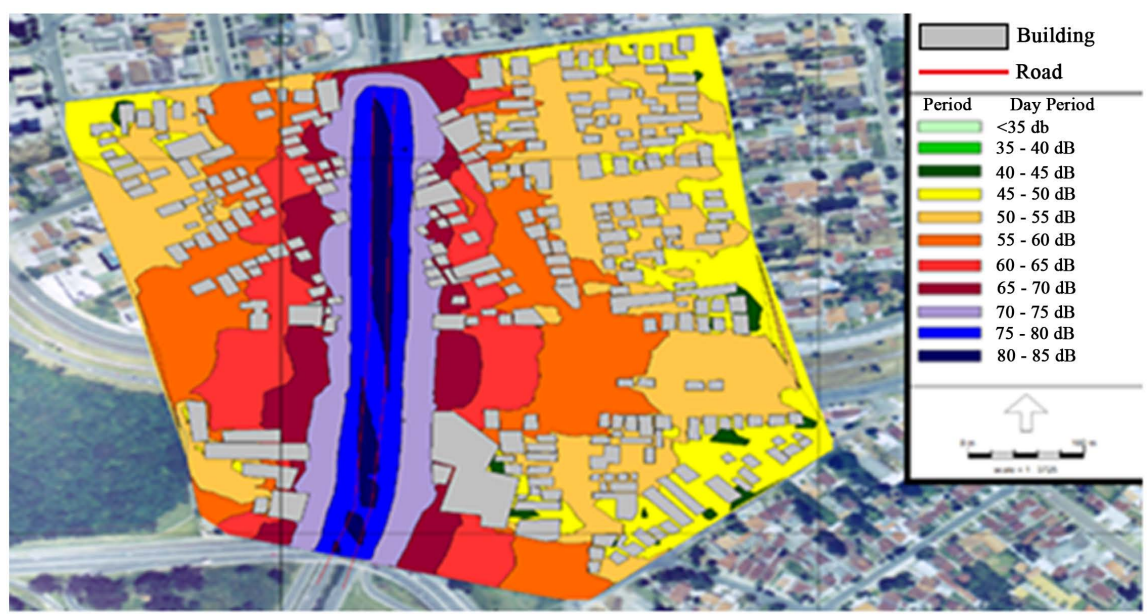

Figure 10. Computer simulation with $10 \%$ of the heavy vehicle traffic, Lot 1 .

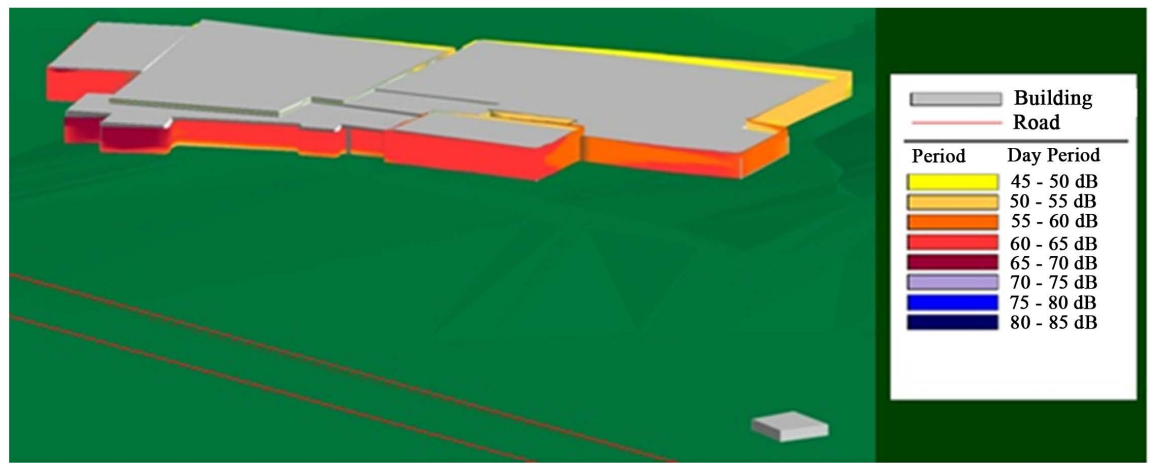

Figure 11. Noise level at the facade of vita hospital.

those considered acceptable by Municipal Law 10625. In the same way, Zannin and Ferraz (2016) present a study about noise around the Clinical Hospital of the Federal University of Paraná, also located in the city of Curitiba, which demonstrates that neither the external nor the internal noise levels are in compliance with current regulations and/or technical standards. Tijunelis et al. (2005) emphasize that: "noise pollution makes errors more probable and is one of the risk factors for provider burnout and negative outcomes for patients".

Busc'h-Vishniac et al. (2005) studied noise levels at Johns Hopkins Hospital in Baltimore. After assessing the sound pressure levels, and the frequency spectra at different locations and at different times within the hospital, they concluded that: "At all locations and all times of day, the Leq - equivalent sound pressure level - indicate that a serious problem exists". They further point out that the "levels found for these acoustic descriptors - may have significant implications for visitors, patients and the hospital staff' (Busch-Vishniac et al. 2005).

Figure 12 represents a gated community located at the Atuba Interchange. Areas such as this one are defined by Municipal Law 9800 as urban residential areas (ZR-4, Table 2), which must comply with the limit of $65 \mathrm{~dB}$ (A) established by Municipal Law no. 10625. 


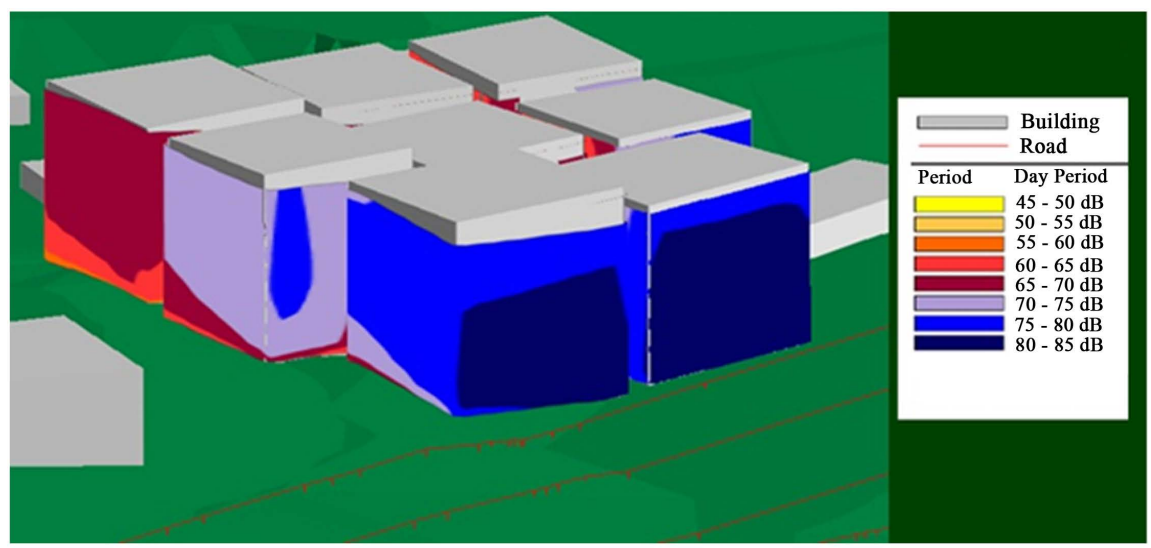

Figure 12. Noise level at the façades of buildings in a gated community located at the Atuba Interchange.

In Figure 12, note that the noise level at the façades of the buildings is very high, reaching 80 to $85 \mathrm{~dB}(\mathrm{~A})$ and 75 to $80 \mathrm{~dB}(\mathrm{~A})$ at the front façades, and 70 to $75 \mathrm{~dB}(\mathrm{~A})$ and 65 to $70 \mathrm{~dB}(\mathrm{~A})$ at the side facades. To minimize the effect of the high noise level on the residents of these apartments, the buildings must be properly insulated.

According to Brazilian Standard NBR 15575-4 (2013), the facades of dwellings subject to intense traffic noise, as is the case of the buildings situated next to the Atuba Interchange (see Figure 12), must have a sound insulation coefficient greater than or equal to $30 \mathrm{~dB}$. However, studies performed in Brazil show that the facade type used in this sort of building provide a sound insulation coefficient around $19 \mathrm{~dB}$ (Oliveira-Filho \& Zannin, 2016). In another study on the insulation of building facades, Ferreira and Zannin (2007) found values between 16 and $21 \mathrm{~dB}$ for popular buildings, and 19 and $23 \mathrm{~dB}$ for high standard buildings. Therefore, the acoustic insulation of the gated Community facade does not provide adequate protection to its occupants and may become, in the near future, a health problem for them (Gozalo \& Morillhas, 2016; Paiva et al., 2019).

\section{Conclusion}

This study was conducted along the urban section of highway BR-116 in the city of Curitiba, called the Green Line North (GLN). The noise levels emitted by vehicle traffic in the GLN were measured in situ. Computer simulations were also performed considering the following parameters: number of light and heavy vehicles, traffic speed, and number and height of buildings in the proximities of the road. Variations of these parameters were applied in order to make simulations aimed at predicting noise pollution along the GLN. The noise limits applied in the evaluations were those established by Curitiba Municipal Law No. 10625/2002 and by the Brazilian standard NBR 10151/2000 for Noise Assessment in Communities.

In general, both the measurements and the simulations indicated that noise pollution is a problem in the study area. These measurements and simulations 
revealed noise levels exceeding the daytime limit of $60 \mathrm{~dB}$ (A) allowed by Curitiba Municipal Law No. 10625. The simulated variations in the proportion of heavy vehicles by half reduced the total sound pressure level by about $1.7 \mathrm{~dB}(\mathrm{~A})$. Therefore, it can be observed that this mitigation action by itself is not enough to solve the noise pollution problem in the area. These results are consistent with those of other international studies.

The sound levels that reach the facades of two buildings - a gated community and a hospital, were also examined and were found to exceed the permissible limits. These two cases represent serious problems, since the people involved will spend a good part of their lives exposed to noise pollution in the case of the gated community. In the case of the hospital, the literature cited here showed that high levels of noise within hospitals can have serious implications, which may increase medical errors and interfere with patient rehabilitation-delaying the recovery of patients. High noise levels can also have negative effects on visitors and on hospital staff in general.

\section{Acknowledgements}

The authors gratefully acknowledge the German Government, through the German Academic Exchange Service-DAAD (Deutscher Akademischer Austauschdienst) and the Brazilian Government, through the National Council for Scientific and Technological Development-CNPq, for their financial support, which enabled the purchase of the sound level meters and software used in this study.

\section{Conflicts of Interest}

The authors declare no conflicts of interest regarding the publication of this paper.

\section{References}

Andrade, K. P., de Oliveira, L. L. A., de Paiva Souza, R. D., \& de Matos, I. M. (2016). Noise Level Measurement and its Effects on Hospital Employees Based on Complaint Reports. Revista CEFAC, 18, 1379-1388. https://doi.org/10.1590/1982-0216201618619815

Applebaum, D., Fowler, S., Fiedler, N., Osinubi, O., \& Robson, M. (2010). The Impact of Environmental Factors on Nursing Stress, Job Satisfaction, and Turnover Intention. The Journal of Nursing Administration, 40, 323-328. https://doi.org/10.1097/NNA.0b013e3181e9393b

Asdrubali, F., \& D'Alessandro, F. (2018). Innovative Approaches for Noise Management in Smart Cities: A Review. Current Pollution Reports, 4, 143-153.

Associação Brasileira de Normas Técnicas (ABNT) (2000). NBR 10.151: Acústica Avaliação do Ruído em Áreas Habitadas, Visando o Conforto da Comunidade Procedimento [Brazilian Association of Technical Standards (ABNT). NBR 10.151: Acoustics - Noise Assessment in Inhabited Areas Aiming at the Community's Comfort - Procedure]. Rio de Janeiro. (In Portuguese)

Babisch, W., Swart, W., Houthuijset, D., Selander, J., Bluhm, G., Pershagen, G., Dimakopoulou, K., Haralabidis, A. S., Katsouy, K., Davou, E., Sourtz, P., Cadum, E., Vig- 
na-Taglianti, F., Floud, S., \& Hansell, A. L. (2012). Exposure Modifiers of the Relationships of Transportation Noise with High Blood Pressure and Noise Annoyance. The Journal of the Acoustical Society of America, 132, 3788-3808. https://doi.org/10.1121/1.4764881

Bies, D. A., \& Hansen, C. H. (2002). Engineering Noise Control: Theory and Practice (2nd Ed., 736 p). New York: Spon Press, Taylor and Francis Group.

Bunn, F., Oliveira Filho, M. M., \& Zannin, P. H. T. (2016). Impacto ambiental sonoro no trecho sul da Linha Verde na cidade de Curitiba, Paraná, Brasil. RA'E GA: o Espaço Geográfico em Análise 38, 7-34. [Environmental Noise Impact in the South Section of the Green Line in the City of Curitiba, Paraná, Brazil.] (In Portuguese).

Busch-Vishniac, I. J. E., West, B. C., Hunter, T., Orellana, D., \& Chivukula, R. (2005). Noise Levels in Johns Hopkins Hospital. The Journal of the Acoustical Society of America, 118, 3629-3645. https://doi.org/10.1121/1.2118327

Dratva, J., Phuleria, H. C., Foraster, M., Gaspoz, J.-M., Keidel, D., Künzli, N., Liu, L.-J. S., Pons, M., Zemp, E., Gerbase, M. W., \& Schindler, C. (2012). Transportation Noise and Blood Pressure in a Population-Based Sample of Adults. Environmental Health Perspectives, 120, 50-55. https://doi.org/10.1289/ehp.1103448

Engel, M. S., \& Zannin, P. H. T. (2017). Noise Assessment of the Area of a Redesigned Urban Expressway Based on Noise Measurements, Noise Maps and Noise Perception Interviews. Noise Control Engineering Journal, 65, 590-610. https://doi.org/10.3397/1/376572

Engel, M. S., Fiebig, A., Pfaffenbach, C., \& Fels, J. A. (2018). Review of Socio-Acoustic Surveys for Soundscape Studies. Current Pollution Reports, 4, 220-239.

Ferreira, J. A. C., \& Zannin, P. H. T. (2007). Determinação de coeficientes de isolamento acústico: medições in situ e simulação computacional (Determination of Acoustical Insulation Coefficients: On Site Measurement and Computational Simulation). Ambiente Construído, 7, 15-29. (In Portuguese)

Fiedler, K., \& Wilhelm, M. (2011). Hygiene/Preventive Medicine/Environmental Medicine. Bremen, London, Boston: UNI-MED Verlag AG. (In German)

Fiedler, P. E. K., \& Zannin, P. H. T. (2015). Evaluation of Noise Pollution in Urban Traffic Hubs-Noise Maps and Measurements. Environmental Impact Assessment Review, 51, 1-9. https://doi.org/10.1016/j.eiar.2014.09.014

Gozalo, G. R., \& Morillas, J. M. B. (2016). Analysis of Sampling Methodologies for Noise Pollution Assessment and the Impact on the Population. International Journal of Environmental Research and Public Health, 13, 490. https://doi.org/10.3390/ijerph13050490

Guedes, I. C. M., Bertoli, S. R., \& Zannin, P. H. T. (2011). Influence of Urban Shapes on Environmental Noise: A Case Study in Aracaju Brazil. Science of the Total Environment, 412, 66-76. https://doi.org/10.1016/j.scitotenv.2011.10.018

Guedes, M., \& Leite, M. J. (2007). Guidelines for the Creation of Noise Maps. Institute of the Environment. (In Portuguese)

Ilic, P., Stojanovic-Bjelic, L., \& Janjus, Z. (2018). Noise Pollution near Health Institutions. Quality of Life, 9, 56-63.

Lee, S.-W., Chang, S. I., \& Park, Y.-M. (2008). Utilizing Noise Mapping for Environmental Impact Assessment in a Downtown Redevelopment Area of Seoul, Korea. Applied Acoustics, 69, 704-714. https://doi.org/10.1016/j.apacoust.2007.02.009

Licitra, G., \& Memoli, G. (2008). Limits and Advantages of Good Practice Guide to Noise Mapping. Paris: Forum Acusticum. https://doi.org/10.1121/1.2932687 
Licitra., G., Ascari, E., \& Fredianelli, L. (2017). Prioritizing Process in Action Plans: A Review of Approaches. Current Pollution Reports, 3, 151-161.

https://doi.org/10.1007/s40726-017-0057-5

Loupa, G., Katikaridis, A., Karali, D., \& Rapsomanikis, S. (2019). Mapping the Noise in a Greek General Hospital. Science of the Total Environment, 646, 923-929.

https://doi.org/10.1016/j.scitotenv.2018.07.315

Mahbub, A. S., Eang, L. S., \& Johnny, W. L. H. (2009). Vertical Profile of Community Noise in High-Rise Built Environment. The Journal of the Acoustical Society of America, 125, 2493-2493. https://doi.org/10.1121/1.4783326

Minichilli, F., Gorini, F., Ascari, E., Bianchi, F., Coi, A., Fredianelli, L., Licitra, G., Manzoli, F., Mezzasalma, L., \& Cori, L. (2018). Annoyance Judgment and Measurements of Environmental Noise: A Focus on Italian Secondary Schools. International Journal of Environmental Research and Public Health, 15, 208.

Morillas, J. M. B., Gozalo, G. R., González, D. M., Moraga, P. A., \& Vílchez-Gómez, R. (2018). Noise Pollution and Urban Planning. Current Pollution Reports, 4, 208-219.

Murphy, E., \& King, E. A. (2010). Strategic Environmental Noise Mapping: Methodological Issues Concerning the Implementation of the EU Environmental Noise Directive and Their Policy Implications. Environment International, 36, 290-298.

https://doi.org/10.1016/j.envint.2009.11.006

Murphy, E., \& King, E. A. (2011). Scenario Analysis and Noise Action Planning: Modelling the Impact of Mitigation Measures on Population Exposure. Applied Acoustics, 72, 487-494. https://doi.org/10.1016/j.apacoust.2010.10.006

Muzet, A. (2007). Environmental Noise, Sleep and Health. Sleep Medicine Reviews, 11, 135-142. https://doi.org/10.1016/j.smrv.2006.09.001

NBR 15575-4 (2013) Associação Brasileira de Normas Técnicas - ABNT. NBR 15575-4: Edificações habitacionais - Desempenho - Parte 4: Requisitos para os sistemas de vedações verticais internas e externas. [Brazilian Association of Technical Standards ABNT. NBR 15575-4: Residential Buildings - Performance Part 4: Requirements for Internal and External Vertical Sealing Systems]. Rio de Janeiro, 2013. (In Portuguese).

Oliveira-Filho, M. V. M., \& Zannin, P. H. T. (2015). Methodology for Assessing the Sound Insulation of the Façade of a Multiple Floor Building. Noise Control Engineering Journal, 63, 152-158. https://doi.org/10.3397/1/376314

Oliveira-Filho, M. V. M., \& Zannin, P. H. T. (2016). Performance of Sound Insulation in Buildings-A Case Study. International Journal of Acoustics and Vibration, 21, 339-345.

Paiva, K. M., Cardoso, M. R. A., \& Zannin, P. H. T. (2019). Exposure to Road Traffic Noise: Annoyance, Perception and Associated Factors among Brazil's Adult Population. Science of the Total Environment, 650, 978-986. https://doi.org/10.1016/j.scitotenv.2018.09.041

Pinto, F. A. N. C., \& Mardones, M. D. M. (2009). Noise Mapping of Densely Populated Neighborhoods-Example of Copacabana, RJ, Brazil. Environmental Monitoring and Assessment, 155, 309-318. https://doi.org/10.1007/s10661-008-0437-9

PMC Prefeitura Municipal de Curitiba (2002). Curitiba Municipal Administration. Municipal Law No. 10625 of 19 Dec 2002-Establishes Regulations on Urban Noise, Public Protection and Welfare, and Makes Other Provisions (9 p.). Diário Oficial do Estado do Paraná. (In Portuguese)

Richard, J. (2013). Advice to Draw up Noise Action Plans in Non Agglomerations. Lärmbekämpfung, 5, 186-191. (In German) 
Richtlinienfür den Lärmschutzan Strassen RLS 90 (1990). Guidelines for Noise Protection in Highways. (In German)

Romeu, J., Genescà, M., Pàmines, T., \& Jimménez, S. (2011). Street Categorization for the Estimation of Day Levels Using Short-Term Measurements. Applied Acoustics, 72, 569-577. https://doi.org/10.1016/j.apacoust.2010.09.012

Tijunelis, M. A., Fitzsullivan, E. S., \& Henderson, S. O. (2005). Noise in the Emergency Department. American Journal of Emergency Medicine, 23, 332-335. https://doi.org/10.1016/j.ajem.2005.02.037

Zannin, P. H. T., \& Ferraz, F. (2016). Assessment of Indoor and Outdoor Noise Pollution at a University Hospital Based on Acoustic Measurements and Noise Mapping. Open Journal of Acoustics, 6, 71-85. https://doi.org/10.4236/oja.2016.64006

Zannin, P. H. T., \& Sant'Ana, D. Q. (2011). Noise Mapping at Different Stages of a Freeway Redevelopment Project-A Case Study in Brazil. Applied Acoustics, 72, 479-486. https://doi.org/10.1016/j.apacoust.2010.09.014

Zannin, P. H. T., Diniz, F. B., \& Barbosa, W. A. (2002). Environmental Noise Pollution in the City of Curitiba, Brazil. Applied Acoustics, 63, 351-358.

https://doi.org/10.1016/S0003-682X(01)00052-4

Zannin, P. H. T., Engel, M. S., Fiedler, P. E. K., \& Bunn, F. (2013a). Characterization of Environmental Noise Based on Noise Measurements, Noise Mapping and Interviews: A Case Study at a University Campus in Brazil. Cities, 31, 317-327. https://doi.org/10.1016/j.cities.2012.09.008

Zannin, P. H. T., Gama, V. L., da Cunha, M. L., Damiani, E. F., Benetti, M., Bianchi, H., da Hora, A. L. S., Guedes, G. B., Portela, T. L., Pinto, V. A. J., \& de Sant'Ana, D. Q. (2013b). Noise Mapping of an Educational Environment. Canadian Acoustics, 40, 27-34. 